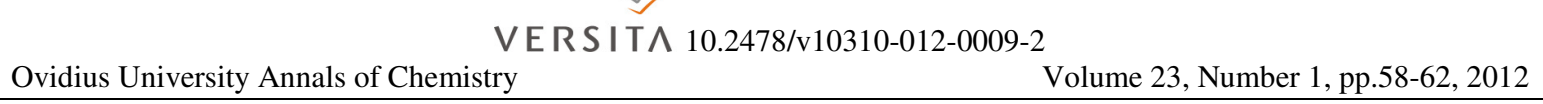

\title{
Study of density and viscosity for ternary mixtures biodiesel+diesel fuel + bioalcohols
}

\author{
Irina NITA and Sibel GEACAI \\ Ovidius University of Constanta, Chemistry and Chemical Engineering Department, 124 Mamaia Blvd, 900527 \\ Constanta, Romania
}

\begin{abstract}
The increase of the environment pollution, together with the instable price of crude oil led in the last years to a renewed focus on biofuels. As the demand in the transport sector is continuously increasing, and taking into account the benefits of biofuels, it is expected that the market demand for biofuels to be increased in the near future. In this context, it will be interesting to investigate if new types of biofuels could be used as mixtures with other fuels for internal combustion engines. The aim of this paper is the study of density and viscosity variation with composition and temperature for ternary mixtures biodiesel + diesel fuel + bioalcohol. Experimental densities and viscosities data for ternary blends diesel fuel+biodiesel +isopropyl alcohol/1-butyl alcohol are presented, and some empirical models proposed to predict these properties for binary systems diesel fuel+biodiesel are evaluated for the proposed ternary blends.
\end{abstract}

Keywords: Biodiesel, bioalcohols, ternary mixtures, density, viscosity

\section{Introduction}

The increase of the environment pollution, together with the instable price of crude oil conducted in the last years to a renewed focus on biofuels. Some biofuels like biodiesel and bioethanol have penetrated the fuel market, their production and use increasing significantly.

As the demand in the transport sector is continuously increasing, and taking into account the benefits of biofuels, it is expected that the market demand for biofuels to be increased in the near future. In this context, it will be interesting to investigate if new types of biofuels could be used as mixtures with other fuels for internal combustion engines.

The physico-chemical properties of biodiesel and its blends with diesel fuel have been extensively studied by several authors [1-14]. The most important properties affecting spray properties, atomization and combustion processes of a fuel are viscosity and density. These properties are used as input data for engine combustion models. Therefore, several studies have been focused on the viscosity and density variation with composition and temperature of binary systems biodiesel + diesel fuel [8-17].

The aim of this paper is the study of density and viscosity variation with composition and temperature for ternary mixtures biodiesel + diesel fuel + bioalcohol. The accuracy of some empirical equations used to evaluate density and respectively viscosity variation with temperature or composition for binary mixtures diesel fuel + biodiesel, are evaluated for the investigated ternary mixtures.

\section{Experimental}

Biodiesel and diesel fuel from local companies were used in this study. Isopropyl alcohol and 1-butyl alcohol (analytical grade) were purchased from Chimopar Company. Some properties of these substances used in the measurements are presented in Table $\mathbf{1}$.

Ternary blends with various compositions were prepared by mixing equal volumes of diesel 
fuel and biodiesel, and adding different volumes of isopropyl alcohol or 1-butyl alcohol. The miscibility of the components was taken into account when making-up mixtures. The content $(\% \mathrm{v} / \mathrm{v})$ of alcohol in the ternary blends was $1.26 \%$, $2.44 \%$ and $3.60 \%$ respectively.

Table 1. Properties of substances used in this study

\begin{tabular}{|c|c|c|c|c|}
\hline Property & $\begin{array}{c}\text { diesel } \\
\text { fuel }\end{array}$ & biodiesel & $\begin{array}{c}\text { iso- } \\
\text { propyl } \\
\text { alcohol }\end{array}$ & $\begin{array}{c}\text { 1-butyl } \\
\text { alcohol }\end{array}$ \\
\hline $\begin{array}{c}\text { Sulfur } \\
\text { content, } \\
\mathrm{mg} / \mathrm{kg}\end{array}$ & 0.14 & 0.0 & - & - \\
\hline $\begin{array}{c}\text { Flash point, } \\
{ }^{\circ} \mathrm{C}\end{array}$ & 68 & 130 & 12 & 31 \\
\hline $\begin{array}{c}\text { Density at } \\
20^{\circ} \mathrm{C}, \mathrm{g} / \mathrm{cm}^{3}\end{array}$ & 0.843 & 0.883 & 0.785 & 0.810 \\
\hline $\begin{array}{c}\text { Refractive } \\
\text { index at } \\
20^{\circ} \mathrm{C}\end{array}$ & 1.467 & 1.454 & 1.377 & 1.398 \\
\hline $\begin{array}{c}\text { Methylic } \\
\text { esters of } \\
\text { fatty acids } \\
\% \text { (w/w) }\end{array}$ & 3.0 & 97.0 & - & - \\
\hline
\end{tabular}

Density of ternary blends were measured using a SVM 3000 viscometer (Anton Paar) equipped with a density measurement cell based on the "U" vibrating tube method. The uncertainty in density measurements was $\pm 0.00005 \mathrm{~g} / \mathrm{cm}^{3}$. Viscosity measurements were carried out using the same equipment, the SVM 3000, having a rotational viscometer cell. The uncertainties of the viscosity values were within the range of $\pm 0.70 \%$. The temperature in the measuring cells was controlled to within $\pm 0.02{ }^{\circ} \mathrm{C}$.

The measurements were conducted in the temperature range of $20{ }^{\circ} \mathrm{C}$ to $50{ }^{\circ} \mathrm{C}$, with an increasing step of 10 degrees. All measurements at each temperature were repeated three times, and the results were averaged.

\section{Results and Discussion}

Density of ternary blends of diesel fuel+ biodiesel+isopropyl alcohol or 1-butyl alcohol was measured from $20{ }^{\circ} \mathrm{C}$ to $50{ }^{\circ} \mathrm{C}$. Experimental results of density measurements of ternary blends diesel fuel+biodiesel+isopropyl alcohol named prop-3.60 $\%$, prop- $2.44 \%$ and prop- $1.23 \%$, indicating the content of alcohol in the ternary systems, are presented in fig. 1 . From fig. 1 it can be observed a linear change in density with the increase of temperature for all the ternary blends, the density of these blends decreasing with a similar rate. For the same temperature, the density of the ternary blends increases with the alcohol content decrease.

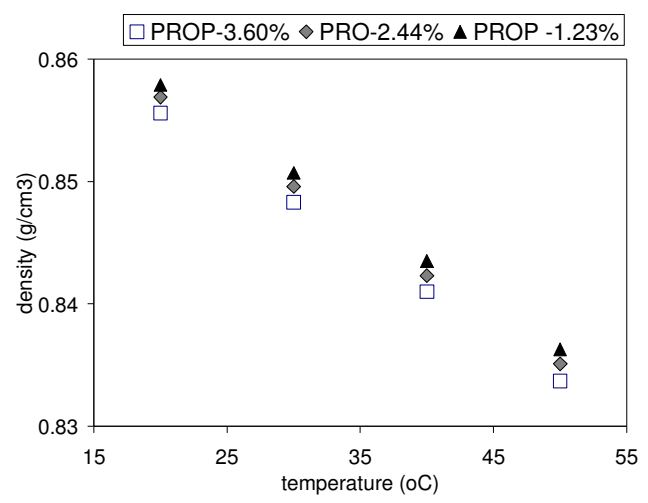

Fig.1. Density of ternary blends diesel fuel+biodiesel+isopropyl alcohol at different alcohol contents as a function of temperature (the name of the blends indicates the percent $(\mathrm{v} / \mathrm{v})$ of isopropyl alcohol in the mixture)

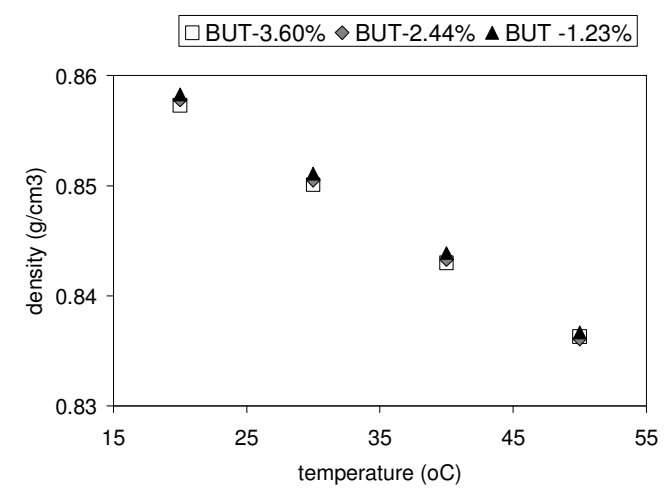

Fig.2. Density of ternary blends diesel fuel+biodiesel+1-butyl alcohol at different alcohol contents as a function of temperature (the name of the blends indicates the percent $(\mathrm{v} / \mathrm{v})$ of 1-butyl alcohol in the mixture)

Figure 2 shows the density variation of three ternary blends diesel fuel+biodiesel+n-butyl alcohol, with temperature. These blends were 
named but-3.60 \%, but-2.44 \% and respectively but-1.23\%, indicating the content of n-butyl alcohol in the ternary systems. The same linear dependence of the density on temperature can be observed in the case of the ternary blends diesel fuel+biodiesel+1-butyl alcohol, as in the case of ternary blends with isopropyl alcohol. At the same temperature, the ternary blends with 1-butyl alcohol had a greater density than the ternary mixtures with isopropyl alcohol. The influence of alcohol content on the ternary blends density is more pronounced in the case of diesel fuel+biodiesel+isopropyl alcohol mixtures, than in the case of diesel fuel+biodiesel+1-butyl alcohol mixtures.

Figures $\mathbf{3}$ and $\mathbf{4}$ present the effect of temperature and alcohol content on kinematic viscosity of diesel fuel+biodiesel+isopropyl alcohol (fig.3) and diesel fuel+biodiesel+n-butyl alcohol (fig.4) blends.

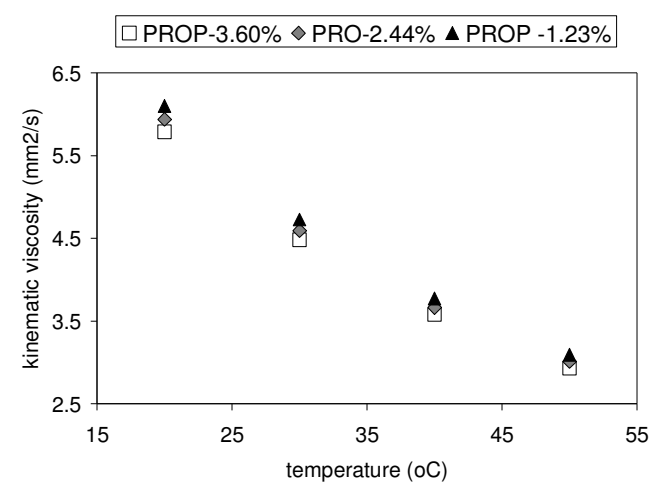

Fig.3. Kinematic viscosity of ternary blends diesel fuel+biodiesel+isopropyl alcohol at three different alcohol contents as a function of temperature (the name of the blends indicates the percent of isopropyl alcohol in the mixture)

From fig. 3 and 4 it can be observed that the kinematic viscosity of ternary blends with isopropyl alcohol or 1-butyl alcohol decreases nonlinearly with temperature increasing.

At a fixed temperature, the ternary blends viscosities decrease with increasing alcohol content in the mixture. The variation of kinematic viscosity with alcohol content is more pronounced in the case of ternary mixtures with isopropyl alcohol, than in the case of the mixtures with n-butyl alcohol.
The dependence of the kinematic viscosity on temperature is more marked in the case of mixtures with the smaller mono-alcohol content $(1.23 \% \mathrm{v} / \mathrm{v})$.

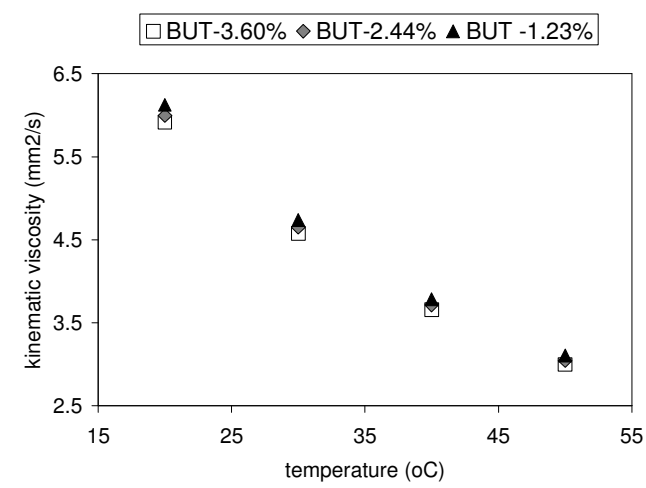

Fig.4. Kinematic viscosity of ternary blends diesel fuel+biodiesel+n-butyl alcohol at different alcohol contents as a function of temperature (the name of the blends indicates the percent of 1-butyl alcohol in the mixture)

The linear dependence of the density of ternary mixtures on temperature or on concentration of mono-alcohols can be expressed by the equation:

$$
d_{\text {blend }}=a Y+b
$$

where $\mathrm{d}$ is the density $\left(\mathrm{g} / \mathrm{cm}^{3}\right) ; \mathrm{Y}$ - temperature or alcohol content in the mixture; $\mathrm{a}$ and $\mathrm{b}$ are correlation parameters.

The value of the correlation parameters for the density dependence on temperature is reported in Table 2, and in Table 3 is reported the value of the correlation parameters for the density dependence on mixtures composition. The correlation parameters were calculated using the least square regression analysis. It can be observed that the dependence of the ternary mixtures diesel fuel+biodiesel+isopropyl alcohol/n-butyl alcohol density on temperature or alcohol content, can be predicted with a good accuracy with the same type of model used for binary mixtures diesel fuel+biodiesel [13-16].

The nonlinear dependence of the kinematic viscosity of ternary mixtures on temperature or on concentration of mono-alcohols can be expressed by the equation: 


$$
\eta_{\text {blend }}=c \cdot Y^{2}+d \cdot Y+e
$$

where $\eta$ is the kinematic viscosity $\left(\mathrm{mm}^{2} / \mathrm{s}\right) ; \mathrm{Y}-$ temperature or alcohol content in the mixture; $\mathrm{c}, \mathrm{d}$ and e are correlation parameters.

Table 2. Correlation parameters for density calculation (eq.1, Y=temperature, ${ }^{\circ} \mathrm{C}$ )

\begin{tabular}{|c|c|c|c|}
\hline \multirow{2}{*}{$\begin{array}{c}\text { Alcohol } \\
\text { content in } \\
\text { the mixture } \\
(\% \mathrm{v} / \mathrm{v})\end{array}$} & \multicolumn{2}{|c|}{$\begin{array}{c}\text { Correlation } \\
\text { parameters (eq.2) }\end{array}$} & $\begin{array}{c}\text { Correlation } \\
\text { coefficient } \\
\left(\mathrm{R}^{2}\right)\end{array}$ \\
\cline { 2 - 4 } $\begin{array}{c}\text { isopropyl } \\
\text { alcohol }\end{array}$ & \multicolumn{3}{|c|}{$\mathrm{Y}=$ temperature } \\
\hline 1.23 & -0.0007 & 0.8723 & 1.0000 \\
\hline 2.44 & -0.0007 & 0.8714 & 1.0000 \\
\hline 3.60 & -0.0007 & 0.8702 & 1.0000 \\
\hline $\begin{array}{c}\mathrm{n}-\mathrm{butyl} \\
\text { alcohol }\end{array}$ & \multicolumn{3}{|c|}{$\mathrm{Y}=$ temperature } \\
\hline 1.23 & -0.0007 & 0.8727 & 1.0000 \\
\hline 2.44 & -0.0007 & 0.8722 & 1.0000 \\
\hline 3.60 & -0.0007 & 0.8712 & 0.9997 \\
\hline \multirow{2}{*}{$\left.* \mathrm{~b}^{*}\left(\mathrm{~g} / \mathrm{cm}^{3}{ }^{\circ} \mathrm{C}\right) ; * * \mathrm{~g} / \mathrm{cm}^{3}\right)$} \\
\hline
\end{tabular}

Table 3. Correlation parameters for density calculation (eq.1, Y=alcohol content in the mixture, $\% \mathrm{v} / \mathrm{v})$

\begin{tabular}{|c|c|c|c|}
\hline \multirow{2}{*}{$\begin{array}{c}\text { Temperature } \\
\left({ }^{\circ} \mathrm{C}\right)\end{array}$} & \multicolumn{2}{|c|}{$\begin{array}{c}\text { Correlation } \\
\text { parameters (eq.2) }\end{array}$} & $\begin{array}{c}\text { Correlation } \\
\text { coefficient } \\
\left(\mathrm{R}^{2}\right)\end{array}$ \\
\cline { 2 - 3 } $\begin{array}{c}\text { isopropyl } \\
\text { alcohol }\end{array}$ & \multicolumn{3}{|c|}{$\begin{array}{c}\mathrm{Y}=\text { volumetric fraction of } \\
\text { isopropyl alcohol }\end{array}$} \\
\hline 20 & -0.0010 & 0.8591 & 0.9924 \\
\hline 30 & -0.0010 & 0.8520 & 0.9964 \\
\hline 40 & -0.0011 & 0.8448 & 0.9988 \\
\hline 50 & -0.0011 & 0.8377 & 0.9968 \\
\hline $\begin{array}{c}\text { n-butyl } \\
\text { alcohol }\end{array}$ & $\mathrm{Y}=$ volumetric fraction of 1-butyl \\
\hline 20 & -0.0004 & 0.8588 & 0.9999 \\
\hline 30 & -0.0004 & 0.8516 & 0.9895 \\
\hline 40 & -0.0004 & 0.8443 & 0.9687 \\
\hline 50 & -0.0003 & 0.8371 & 0.9294 \\
\hline
\end{tabular}

$* \mathrm{a}\left(\mathrm{g} / \mathrm{cm}^{3}\right) ; * * \mathrm{~b}\left(\mathrm{~g} / \mathrm{cm}^{3}\right)$

The value of the correlation parameters for viscosity dependence on temperature is reported in Table 4, and in Table 5 is reported the value of the correlation parameters for viscosity dependence on mixtures composition.

Table 4. Correlation parameters for viscosity calculation (eq.2, $\mathrm{Y}=$ temperature, ${ }^{\circ} \mathrm{C}$ )

\begin{tabular}{|c|c|c|c|c|}
\hline \multirow{2}{*}{$\begin{array}{c}\text { Alcohol } \\
\text { content in } \\
\text { the } \\
\text { mixture } \\
\text { (\% v/v) }\end{array}$} & \multicolumn{3}{|c|}{$\begin{array}{c}\text { Correlation parameters } \\
\text { (eq.2) }\end{array}$} & $\begin{array}{c}\text { Correlation } \\
\text { coefficient } \\
\left(\mathrm{R}^{2}\right)\end{array}$ \\
\cline { 2 - 5 } $\begin{array}{c}\text { isopropyl } \\
\text { alcohol }\end{array}$ & \multicolumn{4}{|c|}{$\mathrm{Y}=$ temperature } \\
\hline 1.23 & 0.0018 & -0.2250 & 9.9033 & 0.9998 \\
\hline 2.44 & 0.0017 & -0.2162 & 9.6371 & 0.9998 \\
\hline 3.60 & 0.0017 & -0.2154 & 9.5395 & 0.9997 \\
\hline $\begin{array}{c}\mathrm{n}-\mathrm{butyl} \\
\text { alcohol }\end{array}$ & \multicolumn{5}{|c|}{$\mathrm{Y}=$ temperature } \\
\hline 1.23 & 0.0017 & -0.2180 & 9.5991 & 0.9998 \\
\hline 2.44 & 0.0017 & -0.2210 & 9.8212 & 0.9998 \\
\hline 3.60 & 0.0017 & -0.2088 & 9.3021 & 0.9998 \\
\hline$\left.* \mathrm{~mm}^{2} / \mathrm{s}^{\circ} \mathrm{C}^{2}\right) ; * * \mathrm{~d}\left(\mathrm{~mm}^{2} / \mathrm{s}^{\circ} \mathrm{C}\right) ; * * \mathrm{e}\left(\mathrm{mm}^{2} / \mathrm{s}\right)$
\end{tabular}

Table 5. Correlation parameters for viscosity calculation (eq.2, $\mathrm{Y}=$ alcohol content in the mixture, $\% \mathrm{v} / \mathrm{v})$

\begin{tabular}{|c|c|c|c|c|}
\hline $\begin{array}{c}\text { Tempera- } \\
\text { ture } \\
\left({ }^{\circ} \mathrm{C}\right)\end{array}$ & \multicolumn{3}{|c|}{$\begin{array}{c}\text { Correlation parameters } \\
\text { (eq.2) }\end{array}$} & $\begin{array}{c}\text { Correlation } \\
\text { coefficient } \\
\left(\mathrm{R}^{2}\right)\end{array}$ \\
\cline { 2 - 5 } $\begin{array}{c}\text { isopropyl } \\
\text { alcohol }\end{array}$ & \multicolumn{4}{|c|}{$\mathrm{Y}=$ volumetric fraction of isopropyl } \\
alcohol \\
\hline 20 & 0.0016 & -0.1411 & 6.2728 & 1.0000 \\
\hline 30 & 0.0081 & -0.1420 & 4.8901 & 1.0000 \\
\hline 40 & 0.0068 & -0.1152 & 3.9060 & 1.0000 \\
\hline 50 & 0.00006 & -0.0684 & 3.1773 & 1.0000 \\
\hline $\begin{array}{c}\mathrm{n} \text { n-butyl } \\
\text { alcohol }\end{array}$ & $\mathrm{Y}=$ volumetric fraction of 1-butyl alcohol \\
\hline 20 & 0.0160 & -0.1646 & 6.303 & 1.0000 \\
\hline 30 & 0.0031 & -0.0819 & 4.8323 & 1.0000 \\
\hline 40 & 0.0034 & -0.0681 & 3.8596 & 1.0000 \\
\hline 50 & 0.0045 & -0.0687 & 3.1836 & 1.0000 \\
\hline
\end{tabular}

As can be seen from Table 4 and 5 , the viscosity of ternary blends diesel fuel+biodiesel +isopropyl alcohol/1-butyl alcohol can be estimated with a good accuracy using the same polynomial equation.

As in the case of density, the dependence of the ternary mixtures diesel fuel+biodiesel+isopropyl alcohol/n-butyl alcohol kinematic viscosity on temperature or alcohol 
62 Study of density and viscosity of ternary mixtures/ Ovidius University Annals of Chemistry 23 (1), 58-62 (2012)

content, can be predicted with a good accuracy with the same type of model used to predict the viscosity of binary mixtures diesel fuel+biodiesel $[13,15]$.

The addition of bioalcohols (isopropyl alcohol or 1-butyl alcohol) to diesel fuel+biodiesel blends improves the density and viscosity of the mixture, these properties being more likely diesel fuel properties.

\section{Conclusions}

Experimental densities and viscosities data for ternary blends diesel fuel+biodiesel +isopropyl alcohol/1-butyl alcohol were presented and the accuracy of empirical models proposed to predict these properties was evaluated.

From this study, the following conclusions can be drawn:

- both density and viscosity of ternary blends diesel fuel+biodiesel +isopropyl alcohol/1-butyl alcohol decrease with the increase of temperature;

- the influence of the alcohol content on the ternary blends density is more pronounced in the case of diesel fuel+biodiesel+isopropyl alcohol mixtures, than in the case of diesel fuel+biodiesel+1-butyl alcohol mixtures;

- at the same temperature, the ternary blends with isopropyl alcohol has a greater kinematic viscosity than the ternary mixtures with 1-butyl alcohol;

- the dependence of the density on the temperature or composition (alcohol content) is of the same nature for the ternary systems diesel fuel+biodiesel+isopropyl alcohol/1-butyl alcohol, as in the case of diesel fuel+biodiesel binary mixtures;

- the estimation of the density using a linear correlation is accurate in the case of ternary blends diesel fuel+biodiesel +isopropyl alcohol/1-butyl alcohol;

- the estimation of the viscosity using a parabolic correlation has a good accuracy for the ternary systems investigated;

-the addition of bioalcohols (isopropyl alcohol or 1butyl alcohol) to diesel fuel+biodiesel blends improves the density and viscosity of the mixture, these properties being more likely diesel fuel properties.

\section{References}

* E-mail address: inita@univ-ovidius.ro

[1] P. Benjumea, J. Agudelo and A. Agudelo, Fuel 87, 2069 (2008).

[2] G. Knothe, Fuel Proc. Technol., 86, 1059 (2005).

[3] W. Yuan, W. Hansen and A.C. Zhang, Fuel 88(6), 1120 (2009).

[4] A. Demirbas, Fuel 87, 1743 (2008).

[5] G. Knothe and K. R. Steidleys, Fuel 84, 1059 (2005).

[6] K. Anand, R.P. Sharma, S. Pramod and S. Mehta, Appl Thermal Eng 31, 235 (2011).

[7] I. Nita and D. Mandalopol, Env Eng Manag J 8(4), 639, (2009).

[8] R.M. Joshi and M.J. Pegg, Fuel 86, 143 (2007).

[9] C.J. Ejim, B.A. Fleck and A. Amirfazli, Fuel 86, 1534 (2007).

[10] M. E. Tat and J. H. Van Gerpen, JAOCS, 76, 1511 (1999).

[11] U. S. Vural, F. Durmaz, O. Kocyigit, H. Kocyigit, V. Muradoglu and B. Akin, Russian J. of Physical Chemistry 82, 2260 (2008).

[12] C. A. W. Allen, K. C. Watts, R. G. Ackman and M. J. Pegg, Fuel 78, 1319 (1999).

[13] A. Tesfa, R. Mishra, F. Gu and N. Powles, Renew Energ 35, 2752 (2010).

[14] I. Nita, S. Geacai and O. Iulian, Renew Energ, 36, 3417, (2011).

[15] E. Alptekin and M. Canakci, Renewable Energy 33, 2623 (2008).

[16] K. Krisnangkura, T. Yimsuwan and R. Pairintra, Fuel 85, 107 (2006).

[17] K. Krisnangkura, C. Sansa-ard, K. Aryusuk, S. Lilitchan and K. Kittiratanapiboon, Fuel, 89, 2775 (2010).

[16] M. Tate, J. Garpen, JAOCS 77(2), 115, (2000).

Submitted: February $15^{\text {th }} 2012$ Accepted in revised form: April $3^{\text {th }} 2012$ 